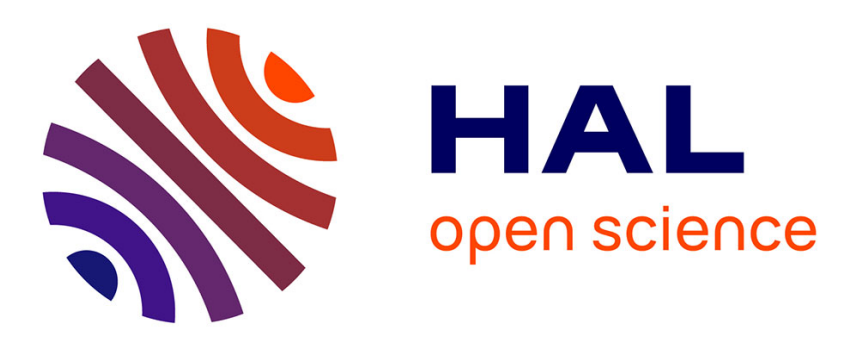

\title{
From colonial domination to the making of the Nation. Ethno-racial categories in censuses and reports and their political uses in Belize, 19th - 20th centuries
}

\author{
Elisabeth Cunin, Odile Hoffmann
}

\section{- To cite this version:}

Elisabeth Cunin, Odile Hoffmann. From colonial domination to the making of the Nation. Ethnoracial categories in censuses and reports and their political uses in Belize, 19th - 20th centuries. Caribbean Studies, 2013, 41 (2), pp.31-60. hal-01053043

\section{HAL Id: hal-01053043 \\ https://hal.science/hal-01053043}

Submitted on 29 Jul 2014

HAL is a multi-disciplinary open access archive for the deposit and dissemination of scientific research documents, whether they are published or not. The documents may come from teaching and research institutions in France or abroad, or from public or private research centers.
L'archive ouverte pluridisciplinaire HAL, est destinée au dépôt et à la diffusion de documents scientifiques de niveau recherche, publiés ou non, émanant des établissements d'enseignement et de recherche français ou étrangers, des laboratoires publics ou privés. 


\section{Elisabeth Cunin, Odile Hoffmann}

From colonial domination to the making of the Nation. Ethno-racial categories in censuses and reports and their political uses in Belize, $19^{\text {th }}-20^{\text {th }}$ centuries

\section{Summary}

This paper presents an analysis of the processes of classification and racial-ethnic categorization of Belize's population during the nineteenth and twentieth centuries, based on population censuses and government reports. We are not too interested in figures as such but in the categories of counting and their evolution, as indicators of the political logic of building a colonial and later a national society. While the censuses for the XIX century relate to different forms of population management (transition from slavery to freedom, affirmation or denial of ethnic and racial diversity), the administrative reports paint a static and stereotyped demographic-territorial model as a tool of the political project. For the twentieth century, we analyze the difficult road to independence and the changes introduced by the new Belizean state (categories, methods, actors) in the process of creating a "national identity".

\section{Keywords in text}

racialization, census categories, Belize, politics of difference, nation

\section{Curriculum}

Elisabeth Cunin is a doctor in sociology (University of Toulouse le Mirail, 2000), researcher at the Institut de Recherche pour le Développement (IRD-France) and at the URMIS (Unité de Recherche Migrations et Société) et the University of Nice. She worked as a guest researcher at CIESAS (Centro de Investigación y Estudios Superiores en Antropología Social) and the University of Quintana Roo in Mexico between 2008 and 2012. Her research deals with social construction of ethnic and racial categories in the case of afrodescendant population, in Colombia, Mexico and Belize. She coordinated the project ANR-AIRD Afrodesc "African Descentants and slaveries: domination, identification and legacies in the Americas (XV-XXI Centuries)" and participated in the European project EURESCL "Slave Trade, Slavery, 
Abolitions and Their Legacies in European Histories and Identities". Her most recent publications: edition of Textos en diáspora. Una antología sobre afrodescendientes en las Américas (México, INAH-CEMCA-IFEA-IRD, 2008); and of Mestizaje, diferencia y nación. "Lo negro" en América Central y el Caribe (México, INAH-UNAM-CEMCA-IRD, colección Africanía, 2010).

Odile Hoffmann received her Ph.D. in geography in 1983 in Bordeaux and a degree in linguistics in Paris that same year. In Mexico, she researched on rural, agrarian and political issues (19841996), and later studied the political dynamics of identity in the black population of Colombia (1996-2002). From 2006 to 2009, she was director of CEMCA, the Centre of Mexican and Central American Studies of the Ministry of Foreign Affairs of France (<http://www.cemca.org.mx>). She continues her research on populations of African origin in Mexico and Central America, within the framework of AFRODESC (www.ird.fr / AFRODESC) coordinated by E. Cunin and in the European project EURESCL she coordinates the Working Group "Building of otherness: circulation and identity in Europe and the Americas". She has published five books, five more as co-author and four as a coordinator, and over 70 articles and book chapters. Personal Website: http://www.odilehoffmann.com 


\section{From colonial domination to the making of the Nation. Ethno-racial categories in censuses and reports and their political uses in Belize, $19^{\text {th }}-20^{\text {th }}$ centuries}

\section{Introduction}

Because of its recent national construction (it became independent in 1981), its history of intensive and diversified migrations and its small size (322,000 inhabitants), Belize offers exceptional conditions for analyzing the contexts of the introduction, dissemination and appropriation of terms and categories referring to the concepts of race, ethnicity and nation. The existing sources allow then to analyze the relations between the socio-historical contexts and the census logics, as well as follow the counting strategy implemented over time and evaluate the capacities of the colonial or national state to build population monitoring tools such as the censuses.

In this article, we will focus on racial and ethnic categories which are used in the population censuses. We will neither work on the categories created and used by social actors in their daily interactions or in specific mobilizations, which have led to the publication of numerous works (Daugaard-Hansen, 2002; Moberg, 1997; M. Palacio, 1995; J. Palacio, 2005; Stone, 1994; Wilk, Chapin, 1990). We will not present an ethnography of the colonial and later national administration, which remains to be done. Our main objective is to study census categories, not as a result or a cause of social dynamics (what they are of course), but in their autonomous administrative logic in two ways:

- Making a long term genealogy of the construction of ethnic and racial categories of census, while questioning what these tools teach us about the capacities and strategies of the colonial then national state apparatus. This is the analysis of the implementation - or non-implementation- of the "national regimes of otherness" (López Caballero, 2011) which involve forms of domination, the definition of otherness and the demands of citizens/ citizenship. 
- Stepping out from the vision of the "all ethnic" or "all racial" of the majority of studies on Belize, while showing that ethnic and racial argumentations appear and disappear, and change in their uses and meanings.

Several authors, for the most part Belizean, U.S. and British, have explored the question of nation building in Belize, and have emphasized history, geo-political negotiations, international relations, and more recently globalization, that is to say the main areas relating to the formation and recognition of "the Nation" in classical terms. In his work, Nigel Bolland (1986, 1997, 2003) analyses the configurations of a colonial society marked by slavery and capitalist extractive exploitation, the concentration of power and the emergence of a "Creole culture". Assad Shoman (1987, 1995, 2000), a major player in the political transition of the years 1970-80, studies the history of the twentieth century, and shows interest in the long road to independence and the institutional and political construction of the new nation. Joseph Palacio (2005) emphasizes the country's ethnic diversity, from the standpoint of the case of the Garifuna. Anne Mc Pherson (2007) highlights the role of women in the hectic and decisive period of the first half of the twentieth century, while Richard Wilk (2006) places the emerging national dynamics in the broader context of globalization(s). With these studies as a starting point, we wish to emphasize here some of the concrete practices of the "construction of the nation", in this case those practices used to describe, name and thus distinguish the "one" from the "other" in a country inhabited by peoples and groups from extremely diverse backgrounds and today known as "creoles", "Garifuna", "Maya", "East-Indians", etc. (see below).

We propose an approach based on a criticism of the specific instruments of the colonial and later national construction, in particular the administrative techniques of the description and classification of the society. As Benedict Anderson reminds us, the very definition of the borders of the State supposes the identification and counting of the individuals and groups that comprise it. "The fiction of the census is that everyone is in it, and that everyone has one - and only one extremely clear place" (Anderson 2003:166).

Three general sets of questions guided our thinking: 
- How is the concept of "diversity" - of origin, nation, religion, "race", ethnicity, etc. — adjusted over time? How do the instruments of population control take into account (or not) the diversity of the population?

- How do these instruments and objectives vary depending on the political-institutional framework (colony, self-government, independence) that produces them?

- If we consider that the question of the census is at the core of the techniques of "making the nation" in the sense expressed by Anderson, how is the question of the Nation, which traditionally equates a territory with a "people" and a "shared culture", expressed in a particularly original colonial context that does not correspond or corresponds wrongly with this scheme?

Coming from academic fields where the references to race and ethnicity are problematic, including France (see CARSED 2009) and Mexico, where they were dissolved in postrevolutionary nationalism, before drawing new relations to the state in the multicultural context of the end of the $20^{\text {th }}$ century (Florescano 1996, Reina 2008, Lomnitz 2001), our epistemological starting point differs from the Anglo-Saxon studies, in which race and ethnicity appear more like "data" (Cunin, 2001). We do not start from the definitions of "race", "ethnicity" or from the competition between "substance" (which would be only from race) and "culture" (unique to ethnicity), but from the ethnization and racialization processes that lead to these notions and keep them alive (Poiret, Hoffmann, Audebert, 2011). Difference is thus created through a balance of power, sometimes mobilizing one dimension over another while modifying its contents and outlines when needed.

Belize $^{1}$ is a small country in Central America, with the Caribbean Sea to the east and with its giant neighbour, Mexico, to the north, Guatemala to the west and Honduras to the south. It is also an Anglophone country in the heart of a Spanish-speaking Central America, with a high percentage of blacks and creoles ${ }^{2}$ in the midst of countries with indigenous and mestizo traditions. It officially became a British colony in 1862, half a century after its neighbours had achieved independence, and it only became independent towards the end of the twentieth century

\footnotetext{
${ }^{1}$ Belize became the colony of British Honduras in 1862, and recovered the name Belize in 1973. It has 322,000 inhabitants according to the 2008 estimate of the Statistical Institute of Belize (http://www.statisticsbelize.org.bz/).

2 "Creole" in Belize refers to the descendants of Europeans (principally British) and Africans.
} 
(1981), long after the last wave of decolonization that began in the 1960s. Belize is often viewed as a piece of the Caribbean stuck in Central America, with a Caribbean façade and a Latino interior, a mosaic of Creoles, indigenous people and Mestizos, but also of Garifuna, Chinese, Indians and Mennonites, a country out of sync with the rest of Central America; there are plenty of contrasting - and often stereotyped-images that seek to describe this territory and its population that do not fit into the models of neighbouring countries.

In fact, although geographically located in the Viceroyalty of New Spain from the sixteenth century, this region evaded Spanish control from the beginning. It was, however, quickly reached by fluctuating populations of sailors, pirates and smugglers, very few in number, who did not seek to found a colony of people but rather to create a "settlement", a living space protected from European military incursions. Faced with these newly-arrived residents, the indigenous Maya Mopan and Kekchi were so discreet that they remained ignored by the administration, almost until the twentieth century (a report by the colonial administration of 1912 ignores them completely, Land in Crown Colonies, 1912). In the North, although they were very few in numbers and relatively inactive, the Yucatec Maya Indians intervened continuously in the daily and political life of the territory (see successive Mayan rebellions until 1872, Bolland 2003). For several decades until 1834, the population was officially comprised of a majority of slaves, some free blacks and "coloured", and a minority of "white" wood cutters (about one tenth of the population). Their British origin allowed them to have a powerful ally, the British crown, defending them to the extent of founding a "colony" in 1862, which nevertheless had to confront Mexican and Guatemalan territorial claims. Some decades earlier, at the beginning of the nineteenth century, a minority Garifuna people (descendent of African and Indigenous people from the island of St Vincent. See González, 1969; Cayetano et Cayetano, 1997) had settled in the south. Although few in number even today (they are predominantly present in only five locations), the Garifuna community is important for its political and cultural roles. Other communities, representatives of classic diasporas in the Caribbean (East Indians, Chinese, Syrian-Lebanese) are also present in Belize since the nineteenth century.

The demographic dynamics, extremely "weak" for centuries, began to take off with the massive influx of refugees from the north, namely Mexico, fleeing the Caste War of Yucatán in the 
second half of the nineteenth century. Several indigenous Mayan groups, "Ladinos", "Mestizos", "Criollos", "Spanish or "Yucatecans" become temporary or permanent migrants, and many settle in the northern half of Belize ${ }^{3}$ and develop its agriculture. In 1893, the Mariscal-Spencer treaty appears as a solution to the border problem between the two countries. Belize does not frown on the demographic consolidation of this portion of its territory, while Mexico seeks above all to pacify the territory and it accepts, albeit reluctantly, this redistribution of the population. On the other hand, tensions remain strong between Belize and Guatemala, even after independence in 1981 and until today. But that's another story. In the first half of the twentieth century there are strong popular mobilizations against extreme poverty and colonial domination, leading to obtaining universal adult suffrage in 1954, the status of "self-government" in 1964, and finally independence in 1981.

The interpretation is based, indeed, on a diachronic analysis of the censuses of Belize, from the first "count" of the population in 1816 to the 2001 census, but more than the "results" (figures) ${ }^{4}$, what interests us here are the elaboration of the censuses, the categories used, the recommendations that accompany the censuses. Thus, from our point of view, the census questionnaires provide as much or more information than the tables of results. This approach follows the proposal of David Kertzer and Dominique Arel (2002) in their work on the role of censuses in the production of collective identities, in particular through ethnic and racial categories. The censuses go far beyond their status as a "technical instrument", and reflect the state of knowledge of the technical and institutional elites of the country at the time of the census. The categories thus become an expression of "the collective", colonial or national, as it is perceived and represented by the elites. But they can in turn influence, and even determine, the relationships between groups thus constructed and classified by the censuses, based on "criteria" presented as ethnic, racial, religious, regional, national, etc. As specified by the two authors, "the use of identity categories in censuses - as in other common mechanisms of state administration — create a particular vision of social reality. All people are assigned to a single

\footnotetext{
${ }^{3}$ The categories are extremely complex, especially as regards the original inhabitants of Yucatan: those called "mestizos" on the Mexican side are classified as "ladinos", "Spaniard", "spanish", and "hispanic" on the British side. The term "mestizo" itself leads to confusion, since in Yucatan it means indigenous people recently "acculturated", while it is applied in the rest of Mexico to individuals that are no longer recognizable as indigenous.

${ }^{4}$ Table 4 gives data on census numbers after 1970 to show the global trends and inform the discussion on the postindependence "ethnic shift".
} 
category, and hence are conceptualized as sharing, with a certain number of others, a common collective identity. This, in turn, encourages people to view the world as composed of distinct groups of people and may focus attention on whatever criteria are utilized to distinguish among these categories" (Kertzer, Arel 2002:5-6).

It is necessary to first consider the diversity of sources and their relationship to each other. During the British period, censuses are accompanied by very informative annual reports. Then we will examine the long process of decolonization and the role of the censuses in building the nation. The tables (see appendix) indicate the sources consulted: Table 1 presents the list of censuses from 1816 to 2001, with reference to their "authors", i.e. the institutions that conducted them; Table 2 gives the list of the colonial reports, a tool of the Belize administration that provides, in particular, numerous descriptions of the population; Table 3 presents the changes of categories since 1946. The data was obtained in the National Archives of Belize in Belmopan and in the ministries and competent administrations. National experts on these matters are not very numerous and their interest in our research was not very evident. The production of categories and data is seen as a very technical issue, carried out by "technicians" supported by people of "good will", that is to say the local political elites. It was only through informal talks and numerous digressions that we managed to have our research objectives understood and thus gain access to relevant sources, in particular the corollary documents that accompany the censuses (methodology, commentaries, etc. $)^{5}$.

\section{Part 1}

$19^{\text {th }}$ century - first half of the $20^{\text {th }}$ century. Defining population and territory, constructing differences.

We begin this account based on the first population censuses, at the beginning of the nineteenth century. At this time, rivalries between European powers did not allow one to speak of a British

\footnotetext{
${ }^{5}$ We made interviews with two groups of people: technicians who often come from abroad, stay for a short period of time and don't have interest in the uses and consequences of ethnic and racial categories; high ranked civil servants, almost never present at the Statistical Institute of Belize and characterized by a strong turn over from an administration to another. Our intuition is that individuals and groups alter census categories both by political and social interests (Nobles 2000) and by very personal, informal, contextual logics of action.
} 
"territory", and Britain's commitment was limited first to accounting for the population within its immediate ambit. Gradually, the fixing of borders and the recognition of Central American countries (end of $19^{\text {th }}$ century) led Britain to favour the economic and political control of territory. Data show that censuses first tend to define and control the population (slaves and later freemen, Yucatec refugees); then their orientation changed and ethnic and racial categories disappeared. At the same time, British administrative reports built a fix model of society, based on the association between identity and territory which ignored the changing categories of censuses.

\section{A slave colony: counting (part of) the population}

Britain's victory against Spain in the Battle of Saint George's Cay, on September 10, 1798, marks, at least symbolically, the insertion of Belizean territory in the British Empire. But the rivalries between colonial powers for the control of Belize were still far from ended, and it did not translate into a new commitment by Britain to develop and administer the territory. This ambiguous situation, between a strategy of domination in relation to Spain, and later to Mexico, and a lack of interest for the local society that was being established, is again reflected in the censuses: since Britain could not, or did not wish to, control a land whose boundaries were problematic and which remained largely unknown and difficult of access, it decided above all to focus on the population. The censuses are thus quite numerous at the beginning of the century $(1816,1820,1823,1826,1829,1832,1835$ and 1840) and draw the portrait of a unique model of slave society, masterfully analyzed by Nigel Bolland (1997, 2003) or Assad Shoman (2000). This model gives priority to slave control (hence the large number of censuses) and the management of the slaves' freedom. The rest of the population (Mayans, Garifunas, Miskitos) is therefore "forgotten" by these first counting tools. A strong socio-administrative consistency is perceptible during the whole period: the census status and the categories used rarely vary, except when it was to account for the transition from slavery to post-slavery (Bolland 1997: 101-130). In parallel, this consistency is the result of the lack of institutionalization, stressed by the rivalries between the oligarchy of the settlers and the Crown representatives. 
In the first half of the nineteenth century, what is at stake is primarily the management of the transition from slavery to its abolition (trade was abolished in 1807 and slavery in 1834) and to take into account a new free non-white population. The censuses of 1816, 1820, 1823, 1826, 1829 and 1832 thus considered four categories: "whites", "coloured", "blacks" and "slaves". Society was conceived and organized around this structural distinction that was only concerned with populations of European and African descent (Bolland 1997). However, already at this time other groups were living in the area: Miskito (Bolland 1997: 88), Garifuna (Bolland 1986: 25; Palacio, 2005), Maya (Bolland 1986: 11; Cal 1983; Shoman 2000: 5). But these did not interest the British administrators, who focused on the port city of Belize from where they managed the exploitation of forest resources.

The censuses of 1835 and 1840 abolished the category of "slaves" and replaced it by "apprenticed labourers": slavery was abolished, but the former slave continued to have a separate status that had to be indicated. Revealingly, the presentation of results is exactly the same before and after abolition (a standard double page table, with a change of name in the last column), and the category "apprenticed labourers" provides the same information (names, ages) as did the category of "slaves". Two dynamics then seem to overlap: the management of slavery and abolition, and the introduction of racialized categories to describe the free population.

\section{The 1861 census: the emergence of multiplicity}

One event altered this mode of perceiving the population: the arrival, from 1847, of refugees fleeing the Caste War of Yucatán in neighbouring Mexico (Cal 1983; Reed 2002; Villalobos González 2006), which becomes obvious in the census of 1861. Although the population was very small in number ${ }^{6}$ (5653 people surveyed in 1826, slightly less - 4235 - three years later), it increased significantly in 1861 (25,635 inhabitants), with nearly half the population in the north, on the border with Mexico.

\footnotetext{
${ }^{6}$ And probably underestimated, as the British administrators themselves admit, particularly because of the poor return of questionnaires sent to forestry workers.
} 
The census of 1861 appears to be an exception, with its multiplication of categories of ethnic, racial, and national identity, and their components. It is also, as Michael A. Camille (1996) reminds us very well, the culmination of two centuries of history in Belize. Finally, it is the first attempt to take into account the diversity of the population.

In the census of 1861, the criterion described as "race" actually refers to a number of categories (42) that seek to take account of the diversity of the population. The designations mixed references to 'race', language or nationality, with a luxury of details: Anglo-Hispanic, distinguished from Spanish-English, or French-Portuguese from Portuguese-French, for example. Then there are eight categories only for the "English": Anglo-Saxon, AngloHonduran, Anglo-African, Anglo American, Anglo-Indian, Anglo-Hispanic, Anglo-French, Anglo-Carib. This census shows the emphasis on defining and describing the categories of mixes based on multiple and non-hierarchical criteria. Many refer to nationality, but more generic (“coolies") or ethnic (“Carib", "Indian”) descriptions are interposed "as needed". Thus, while the censuses at the beginning of the $19^{\text {th }}$ century only took into account the "white" and "black" population and their mixtures, the census of 1861 introduced some of the categories that would last (with some adjustments that we will comment on later): “Anglo", “African", "Indian”, "Spanish", "Carib", "Syrians", "Chinese", "coolies". Finally, it should be noted that the nationalities mentioned all refer to European nationalities and exclude, in particular, Mexico and Central American countries. These "young nations" were, nonetheless, recognized by Great Britain from 1824-1825 in the case of Mexico, and from 1839 (end of the federal republic of Central America) in the case of Guatemala. But they did not seem to be relevant for the administrators in charge of the census, who have a strictly European focus. In 1859, a treaty between Great Britain and Guatemala fixed the border between the latter country and the future British Honduras. It was questioned in the 1930s and continued to fuel conflicts between both countries to the point of causing the delay of Belize's independence (Shoman 2000). We can notice, with Camille (1996), that this critical time in the history of Belize (the decline of mahogany, the beginning of agriculture with the settlements of the north and the migrations of foreign workers) is also a pivotal period for its political and diplomatic history, with the declaration of the colony in 1862. The census of 1861 falls within these changes. A number of the composite categories it produced would not be used later, but they reflect the dynamism of 
the population on the one hand, and the willingness to describe it on the other. At the same time, and we will return to this point, the accuracy of these data does not really seem relevant within a scheme of population control and this multiplicity of categories were no referred to by colonial administrators.

The turn of the $19^{\text {th }}-20^{\text {th }}$ centuries: consolidation of the colony

The second half of the nineteenth century witnessed a strengthening of the British presence in Belize, with the official adoption of the status of colony in 1862. According to Assad Shoman, political power at that time passes from the settlers to the Colonial Office in London (Shoman 2000: 101). While the Central American neighbours were already independent, it became necessary to reaffirm the British presence in the region. Relations with the new Central American nations were normalized and, in 1893, the Mariscal-Spencer treaty defined the border between Mexico and Belize. Having established the institutional (colony) and diplomatic (borders) framework, Britain could dedicate itself more directly to the control of its official territory whose territorial limits are recognized. Censuses of the time demonstrate this: in the late nineteenth century $(1871,1881,1891)$ and early twentieth century $(1911,1921,1931)$, there is no mention of racial/ethnic groups. ${ }^{7}$ This logic is present throughout Central America at the same period where liberal governments tried to eliminate racialized categories (Gould 1998). It is also about asserting the British presence, which is specified through the control of the territory; identification with the colonial policy replaces the ethnic-racial identifications. We find here the "classical" vision of nineteenth century imperialism, which associates territory, people, state and nation- a vision crystallized in the Berlin conference of 1890 and derived from the "Westphalian model" which imposed an international order made of strictly equal and sovereign entities in the $17^{\text {th }}$ century (Badie 1995). In fact, with the turn of the century the logic that prevails is above all that of the management of the territory, rather than of the population as before, and the political affirmation of sovereignty over the colony. Migrations were still

\footnotetext{
${ }^{7}$ It is interesting to note that, in the 1901 census, there is a summary of the earlier censuses $(1826,1829$, $1832 \mathrm{y}$ 1835): the division in the four categories we have already described are transformed to a very different classification of "free persons", "slaves" and "troops", as if the original racial logic were reinterpreted in light of a focus that privileges status and not racial belonging. The mention of "troops" is no accident in this period (1820-1830) when the territory of Belize acquired a commercial strategic importance for all of Central America torn by the wars of independence and their consequences. It was necessary to protect ports and transport vehicles.
} 
considerable (manual workers moving to the forest concessions of southern Mexico, workforce from India and China, white North-American settlers) but were by then largely controlled by the colonial administration. This administration took advantage of migration in order to develop the economy (small scale agriculture, cane sugar, etc.), increase tax resources (taxation of wood and chicle from Mexico), and consolidate its territory.

The end of the Caste War and the new presence of the Mexican state at the northern border (creation of the territory of Quintana Roo) put an end to the migrations from Mexico to Belize and opened the way for return migration, this time from Belize to Mexico. The 1870s had already seen the end of the conflict with the Chichanhá Mayans by the defeat and the death of Marcos Canul in 1872 (Cal 1983; May Zalasar 2010), which led to the pacification of the North of Belize. The very image of the Mayans, who until then were excluded and regarded as potential enemies, began to change. The Mayans and the Garifunas started then to be integrated into history and national society (Bolland 2003 : 123), especially in the implementation of the system of "alcaldes" (Bolland 2003: 129, Moberg 1992) and in their participation in the development of agriculture and fishery.

At the same time debates begin to develop around these people of Mexican origin who decided to stay in Belize: rather than "Spanish" or "Ladino", they should be regarded as "British" and swear allegiance to the British crown. This is how, at the time of the celebration of the centenary of the Battle of Saint George (1798) and the birth of the "founding myth" of Belizean society (Macpherson 2003), the descendants from the Spanish are asked to adhere to the British empire.

\section{Building a permanent model}

At the turn of the century, the emergence of a local elite who questioned British power (Unofficial Majority between 1890 and 1930) and then the mobilizations of workers in a dramatic socio-economical context (Ashdown 1985, Soberanis and Kemp 1949, Macpherson 2007) facilitated the appearance of a "Creole society" (Shoman 2000 : 125) and a dynamic of "Creolisation" (Bolland 1986 : 53, Judd 1990), both tending to integrate differences into a common political project (whether colonial or pre-national). However, the disappearance of 
ethnic and racial data in the censuses does not prevent its continued use elsewhere; hence, it does not obviously correspond to a disappearance of ethnic and racial distinctions within the society. It is precisely one of the issues we consider major to stress: there might be some discrepancies, even contradictions between some social behaviours and logics of action, inspired by objectives, specific interests and multiple contexts. That is indeed where the driving force of social changes lies.

Parallel to the population censuses, regular reports were prepared that aimed to summarize the main information on Belize; these reports address many fields (history, economics, infrastructure, etc.), including the population. They were published regularly in London, then in Belize between 1888 and 1965, and are divided into three types: Colonial Reports, Handbooks and Blue Books (see table 2). While the previously studied censuses aimed to provide an increasingly accurate account of the composition of the population (ending in the extreme case of 1861), and later ignored the ethnic and racial distinctions (from 1871 to 1931), these reports appear to construct a social reality without reference to the censuses. By this means they forged a stereotyped and immutable image of the different groups, associating them with a delimited territory and with the history of their arrival in Belize. One thereby notes a form of institutional repetition that draws an invariable model of the demographic configuration of Belize and justifies a standardized policy, known as "divide and rule". The reports of the British administration reveal an impressive continuity of ethnic and racial distinction, while the census categories and figures are perfectly discontinuous, in a discrepancy between the quantification tools and their use. We illustrate this from the case of the Handbook of British Honduras, 18881889, but the same conclusions could have been drawn from any other administrative document of the whole period (end of $19^{\text {th }}$ and middle of $20^{\text {th }}$ century) since their content is similar. The Handbook of British Honduras, 1888-1889, by Lindsay Bristowe and Philip Wright, representatives of the British crown, describes four categories: the "natives", the "Ladinos", also called "Spaniards" or "the Spanish element", the "colored" or "Creole" and "Caribs". The former occupy the north of the territory, "they live in villages industriously and inoffensively scattered over the [Northern and North-Western] district, cultivating their patches of maize and pulse in small and neatly enclosed fields known as milpa". The "Ladinos", also located to the north and of Spanish and indigenous descent, are characterized by a "freedom of thought and manners, as 
well as information and enterprise. To this class most of the artisans and operatives belong" (Bristowe and Wright 1888-1889: 201-202). With regard to the Caribs of the southern region, it is recalled that "the usual division of labour among savage nations is observed by them. The daily drudgery of the household belongs to the women, who also cultivate the small fields in which the cassava (...) and other crops are raised. The men pursue their hunting and fishing, and undertake the more severe labour attendant upon the building of their huts" (Bristowe and Wright 1888-1889:203). Finally, they state that the Creoles, "of European and African descent", live mainly in the centre of the country and form "a hardy, strong, and vigorous race of people, who are the woodcutters of the interior, and the main instrument in keeping up the commerce of the colony" (Bristowe and Wright 1888-1889:202).

There is thus established a population/territory association based on a stereotypical classification of people (identity, occupation): the Indians and "Spanish" mestizos in the north, blacks, Creoles and Garifuna in the centre and south. This general pattern remained unchanged until 1965, the date of the last report upon Belize obtaining the status of "self-government" (1964). In the Colonial Reports, this description is repeated in an identical manner for long periods (1931$1938,1946-1950,1954-1957)$ and the changes in the entire period (1898-1965) are negligible. The repetition seems to comply with a mandatory annual report function directed at the metropolis rather than an attempt at updated analysis: "the Corozal and Orange Walk Districts are inhabited principally by the descendants of the Spanish and Maya peoples. The Stann Creek District is peopled, in the main, by Caribs, while in the Toledo District Caribs and Maya predominate. In the Cayo District are Guatemaltecans, Mexicans and a few Syrians. In the Capital the "Creoles" (descendents of the early settlers) are in the majority, but there are also a large number of people of Latin extraction from the neighbouring republics, and Syrians and Chinese. There is a limited number of Europeans and US citizens" (Colonial Report 1931).

However, a comment that is also repeated accompanies this description: "owing to intermixing, racial classification of the population is difficult and unreliable". The reports are, therefore, based on the repetition of an ethno-racial model, while insisting that miscegenation prevents the classification of people by racial criteria... Thus, there is both a recognition and a denial of racial mixing; in fact, its evocation helps to revalidate the original" categories (Spanish, Creoles, 
Caribs, Maya), while integrating new groups defined on the basis of nationality (Mexican, Guatemalan, Syrians, Chinese). The British settlers are not contemplated in this scheme, while all "others" are considered as migrants. This view includes the Maya, who are denied their autochthonous condition, as it is shown in a 1912 report addressed to the colonial office by Acting Governor Wilfred Collet: "It may, perhaps, be well for me to mention that the only aboriginal natives of America in the Colony are either immigrants or the descendants of persons who came to the Colony after it became a British possession" (Land In Crown Colonies 1912:39). While not escaping the assignation of an identity, the Creoles represent, because they are closer to the "whites", the foundation of the society: the Creoles, "together with the whites, are, in fact, the backbone of the colony" (Bristowe and Wright 1888-1889:202).

Great Britain establishes, in short, a model of society that blends racial, cultural and geographical characteristics and in which "everyone has his place" and that at the same time that the censuses abandon the ethnic-racial categories (end of the $19^{\text {th }}$ century and beginning of the $20^{\text {th }}$ ). This conception of otherness, based on the anteriority of migrations and on the negation of autochthony, justifies the domination of a small group: the first European immigrants supported by the "Creoles", who have an ambiguous status, at once "other" and founders of this society.

\section{Part two:}

\section{the slow march toward independence. What nation to construct?}

Numerous works focus on this second part of the $20^{\text {th }}$ century to analyze the emergence of an independent nation in relation to ethnic and racial backgrounds (Bolland 1986, Wilk 1993, Price and Price 1995, Shoman 2010). The $20^{\text {th }}$ century can also be considered, in the case of Belize, as a period of multiple ethnic and racial negotiations and arrangements. The articulation of the nation, race, and ethnicity, have given birth to the identification of three models of nationalism (pluralist, synthetic, hegemonic, Medina 1997) which overlap and cross over with each other depending on the context and the actors involved, rather than excluding and following one another.

In the early twentieth century, the first convulsions, mainly social and economic, acquired a 
political dimension. However, there is still no talk of independence. The priority is the phenomenon of extreme poverty, at times of hunger, which leads to race riots in 1919 (Ashdown 1985) and the birth of trade unions. As in the rest of Central America (anti-Garifuna demonstrations in Honduras, harshly repressed popular uprisings in El Salvador), the 1930s are agitated. In Belize, the hurricane of 1931 exacerbated popular mobilization. This is heightened after the Second World War, in reaction to the devaluation (1949), and it is organized around the foundation of the first local political party, the People's United Party (PUP, 1950) and the national strike of 1952. The colonial government conceded universal adult suffrage in 1954, proclaimed "self-government" in Belize in 1964, and from the 1960s, approved the independence of the other territories of the West Indies. Belize's independence was delayed until 1981, principally because of the border dispute with Guatemala (Shoman 2000).

To what extent did the censuses interpret or report on these radical transformations of society, first organized under a colonial system and then as an independent nation? We shall proceed as for the previous period, analyzing the categories used and their evolution (see table No. 3).

\section{From 1946 until the eve of independence.}

This period is marked by three censuses, in $1946,1960^{8}$ and 1970 . They are developed within the general framework of the West Indies and implemented in Belize, with the clear intention of comparison with the Anglophone Caribbean grouping. Thus, in 1946, the census is applied simultaneously in Barbados, British Guiana, British Honduras (Belize), the Leeward Islands, Trinidad and Tobago, Dominica, Grenada, St. Lucia and St. Vincent. This is the first census planned for the whole of the West Indies and it includes a detailed list of identical instructions to all the colonies involved. It represents an intention to affirm the strength and unity of the British Empire. We are here faced primarily with a logic of insertion in the imperial project and of the almost mechanical management of territories and populations.

\footnotetext{
${ }^{8}$ The results of the census of 1960 have not been published. This census might have been at the core of tensions between the British administration (which imposed a unique model of census to the entire West Indies) and George Price, leader of the independence movement, stressing national unity, on the eve of obtaining the status of selfgovernment in 1964.
} 
At the same time, however, the comments included in the census show the extent to which Belize is different from the rest of the West Indies. Thus, in the censuses of 1946 and 1970, a specific paragraph is directed generally at Belize (as well as British Guiana), recalling the difficulty of integrating it into the general pattern of the West Indies: it is considered as "less racially homogeneous", the percentage of its Amerindian population is more important, and it contains almost the totality of the "Caribs" (Garifuna) of the West Indies. Despite this, and if this situation of difference is properly diagnosed, Belize is too small, too sparsely populated and does not merit the development of new categories or an adaptation of the general model of the census. This importation of categories reached ridiculous lengths, for example, with the "Portuguese" that appear in the census of 1970 only because they are present in other parts of the West Indies (as in British Guiana, see Christopher, 2005: 108), but this does not correspond to any reality in Belize. Or the case of the disappearance of the category Carib/Garifuna in 1960 and 1970 because this group only exists in Belize and is not considered important enough to be recognized as a census category in the rest of the West Indies.

One of the liveliest debates is about the question of mixed categories. In effect, the criteria that take mixtures into account are transformed: in 1946, it was recommended to classify as "blacks" the children of "mixed" and "black" (1946:16). However, this approach changes as from 1970; and particular care is taken with the "so-called Mixed group". Children born to "mixed" parents or to members of two different racial groups should be classified as "mixed". Distancing itself in this way from the British policy of "divide and rule" that tends to distinguish each ethnic category, the census of 1970, drawn to the scale of the West Indies, prefers to insist on the mixed categories and not on those that refer to a single origin. At that time when many British colonies achieved independence (and Belize its "self-government"), we of course wonder about this coincidence between the statistical appreciation of mixed groups and the construction of national identities: disappearance of the categories linked with colonization and slavery, emphasize on a mixed population as a symbol of the new nation.

In the case of Belize, taking mixed groups into account is even more complex. In effect, miscegenation in the West Indies relates above all to the descendants of African origin mixed with those of European or Asian origin. The classic works of Michael Garfield Smith (1965), 
will legitimate the idea of the dual nature of the composition of Belize, divided into a "negrowhite Creole" and a "Spanish-Indian mestizo" population, a legacy of the migrations caused by the Caste War. Despite their efforts to integrate the mixture of races, the censuses fashioned in the West Indies fail to grasp this "other" miscegenation that refers to the descendants of indigenous and Hispanic populations. There is thus observed in the 1970 census a certain importance given to the category "other races", which brings together individuals who are not recognized in any of the existing categories, and which amounts to $11.5 \%$ of the population.

Neither do the years of struggle for independence and for workers' rights rely on the ethnic identification of the population ${ }^{9}$. One thus finds a paradox or tension between two visions/practices: on the one hand a mobilization toward independence that seeks to overcome differences, and on the other hand census categories produced by the British administration that reaffirms the existence of ethnic groups.

Independence. Censuses of 1981, 1991 and 2001.

Did independence imply that "the Nation" should privilege "creolization" to the detriment of the previous racial and ethnic classifications? Was there a desire to create distance from the association of territory-population so compelling in the colonial representations of the various reports, and thereby forge a new vision of the national society? How do the censuses reflect this? We do not have, in fact, all the elements necessary to answer these general questions; however, an analysis of changes in categories provides clues to understand this nation under construction.

In general, according to the terms used in the technical documents of the censuses, there are considered racial categories (1946, 1970, 1981), racial and ethnic (1960), racial, ethnic and national (1991) and ethnic (2001). Beyond the general classifications, the categories used generally mix references to "race", ethnicity, nation, and even religion. The census of 2001 seems closer to international standards promoted especially by international agencies, as shown

\footnotetext{
${ }^{9}$ The position of George Price, "father of the Nation", was quite ambiguous: he sought to forge national unity in a multi-ethnic society but was sometimes perceived as favoring the Mayas or, on the contrary, as avoiding ethnicised politics (for example in the organization and discourse of his political party, the PUP). .
} 
in particular by the use of the category "Caucasian/ white" or the abandonment of references to "race".

For the period 1946-2001 there are observed, for some categories, changes that are above all adjustments. Even if the name is changed, there seems to be no confusion about the boundaries that the appellation represents, as for example the "whites" (1946, 1970, 1981, 1991), classified as "European (or white)" in 1960 and "white/Caucasian" in 2001 (in 1861, the term used was "Anglo-Saxon"), the category "Syrian" becomes "Syrian-Lebanese "in 1970 before disappearing in 2001, the categories "Chinese" and "East Indian" (reminiscent of the "coolies" of 1861) do not change, except in 1960 for the former ("Chinese" and "Japanese") and in 1991 for the latter ("Indian" instead of "East Indian"), the category "German/Dutch/Mennonite" appears in 1991 and is transformed into "Mennonite" in 2001, abandoning the European reference. These categories are never questioned, even though their names vary. They are "natural" and naturalized. They are the results of a consensus on ethnic barriers as described by Wimmer (2008: 973).

There is observed, however, two significant evolutions in our subject, noted in the change from categories developed in the framework of the West Indies to categories increasingly elaborated locally. While the 1981 census still partially depended on the institutions of the West Indies, the 1991 census was the first to be fully developed locally, causing some rivalries between two institutions of the new nation, the Central Statistical Office and the Ministry of Home Affairs, the first being finally left in charge of the census. These changes directly question the relationship between categories of the census and national independence.

First, there is noted the emergence of a logic of ethnicization for two groups, the Garifuna and the Maya, based on the use of categories of self-designation. The former are identified with the colonial term "Caribs" until 1946, they disappear in 1960 and 1970, and then return with the name of Garifuna in 1981, 1991 and 2001. The latter are labelled with the generic terms "Indians" in 1861, "American Indians" in 1946 and "Amerindians" in 1970 (they were not counted in 1960), and then are differentiated as "Maya" and "Kekchi" in 1970, "Mopan", "Kekchi" and "other Mayas" in 1991, and finally "Mopan", "Kekchi" and "Yucatec" in 
2001. There is thus noted an emphasis on multi-ethnicity (Wilk and Chapin 1990, Izard 2004), at the very time of the independence of Belize.

In contradiction to the independence and nationalist discourse, which aims to transcend ethnic differences, censuses, already being produced locally, promote the consolidation/ development/redefinition of ethnic groups, a process that is confirmed by the social dynamics. As if echoing the observed changes in the categories beginning with the 1981 census, there is a renewed affirmation of the ethnicization of certain groups, mainly Garifuna and Maya. The appearance of two ethnic organizations, the National Garifuna Council (in 1981) and the Toledo Maya Cultural Council (created in 1978, but mostly active from the mid-1980s), is a symptom of those changes. If your ethnicity was formerly synonymous with marginalization and inferiority, it now becomes, in the new globalized multicultural landscape of the years 1980-90, an identity vector valued by the Maya and Garifuna peoples themselves.

In the case of the Garifuna, the existence of a specific language, religious rites (dügu), the transnational community (Honduras, Guatemala, Nicaragua, Belize and the United States), the wealth of musical forms (paranda, punta, punta rock, etc.) is used as an argument to highlight both their difference and their "authenticity" (González 1969, Foster 1986, Cayetano and Cayetano 1997, Izard 2004, Palacio 2005). Their language, dances and songs were given the status of Intangible Heritage of Humanity by UNESCO in 2001. For its part, while the Toledo Maya Cultural Council works primarily on the recovery of Maya history and culture, it was able to take advantage of a developing heritage tourism (exploitation of Mayan archaeological and natural sites) and also engage in a more assertive course, as is witnessed particularly in the debates surrounding the creation of a "Maya homeland" in the 1980s or its participation in a network of Mesoamerican Mayan NGOs. As in its neighbouring countries, these initiatives come with extremely practical claims, especially in land and territorial claims (Berkey 1994, Tzec et al. 2004). The political dimension of this re-ethnicization is not expressed through an explicit political commitment (political parties, ethnic vote, specific claims) but rather serves to weaken a bit more a model of "creole society" that had been established so far on the basis of inclusion regardless of the Garifuna and Maya: as Belizean citizens who did not embody the nation Belize. 
The second development relates to two more problematic processes (at least in terms of analysis), which will detain us at greater length: the change of the categories of "African" (1861), "black" (1946), "African (black)" (1960) and "black" (1970) to those of "creole" as from 1981, and the change of the categories of "mixed or coloured" in 1946 "other races and all other mixed races" in 1960, and "mixed" in 1970, to the category of "mestizo" after 1981. This demonstrates a strong desire to change in 1981, resulting in the presentation of a country essentially "Creole" and "mestizo", terms that appear because of a concern to account for the ethnic and racial composition of the country and to utilize the categories in use in Belize. However, such a modification of the categories remains questionable: in effect, it supposes an equivalence between, on one hand, the terms "black", "African", and "Creole" and on the other hand, between the words "mixed" and "mestizo". 10

In Belize, the term "mestizo" refers to a precise historical event that defines a population: the descendants of migrants who came from Yucatan in the second half of the nineteenth century, fleeing the violence of the Caste War. It is, in some form, an ethnonym, as opposed to "mixed", which defines a state of mixture, and unlike the common meaning of the word "mestizo" in Central America and Mexico, which refers to the descendants of Spaniards and indigenous people. Now then, as we have seen, this category was introduced in 1981, when a wave of Central American migration enters Belize, beginning at the end of the 1970s (political and economic migrants arriving mainly from Guatemala, El Salvador and Honduras): The ethnonym that specifically designated refugees from the Caste War of the $19^{\text {th }}$ century began to be used, in the census, to designate all those who have in common the Spanish language or "Latin culture". This administrative assimilation, founded on origins and sometimes language, is not the sign of social assimilation. Indeed, numerous mestizo Belizeans do not consider themselves in organic solidarity with the mestizos of Central America but rather see themselves in competition in the areas of access to work, land and public services (Medina 1997, Moberg 1997).

\footnotetext{
${ }^{10}$ The significant confusions that occurred during the census of 1981 demonstrate that this transformation was not carried out without errors: while the questionnaire for 1981 introduced the new categories of "creole" and "mestizo", some analyses of the census repeated the old categories of "black " and "mixed" (1980-1981: iv, 110, 1991, Population Census. Major Findings: 6). Simultaneously, the results of 1970 were presented with the categories used in 1981 (changing "black" to "Creole" and "mixed" to "mestizo").
} 
The political context becomes heavily loaded, at the time of the independence of Belize; the new nation has to deal with both ethnic claims and non-ethnic nationalism, at the very time the relations between creoles and mestizo groups get more difficult. In fact, in the 1991 census, the "mestizo" population is greater than the "creole". 11 The statistics are the order of the day, and observers (the media, intellectuals) are concerned about this "ethnic shift" that disrupts the face of the new nation (see for example Wilk 1993). In this sense, far from being an instrument of population control, the censuses rather symbolize the birth of a state that has not yet perfectly mastered the instruments of power. The introduction of ethnic categories of self-designation (Garifuna, different Maya groups) and the use of the extremely heterogeneous term "mestizo" have statistically produced a society which does not correspond neither to an integration of ethnic groups or an overcoming of ethnic differences, nor to the hegemony of the Creole society.

\section{Conclusion}

While Belize is systematically associated with ethnic issues, we wanted to demonstrate that ethnicity is unstable across time, and that while it was often structuring and mobilized, it can also be absent or underestimated at other times. The censuses thus confirm that the ethnic and racial categories disappeared sometimes from the full range of tools for defining and controlling the population; and they evolved considerably as the institutions changed. The nationalist ideology of inclusion, with two main categories ("creole" and "mestizo") gave way to the assertion of ethnic and racial identities in the neo-liberal and multicultural environment of the 1990s and 2000s, but this renewed assertion is no longer comparable with the multiplicity of categories used in the 1861 census. Belize grounding in the Anglophone Caribbean, which is directed towards an ethnic administration of the populations, should not obscure the considerable variations in the management of ethnicity and in the very definition of these categories. These variations may be related to the precarious status of the territory, in dispute between Spain/Mexico and Great Britain until 1862, and then a British enclave in the midst of independent Spanish speaking countries.

\footnotetext{
11 In a symbolic manner, the 2001 census presents its results beginning with the "mestizos" (who became numerically more important), whereas the first column of the tables was until then reserved for the "blacks/Africans" or the "Creoles".
} 
The first censuses in the nineteenth century manage the issue of the transition from slavery to freedom and focus on only a portion of the population, of European and African origin, concentrated in Belize City. The arrival of refugees from the Yucatan Caste War in the midnineteenth century implies a change of perspective, and the census of 1861 aims, with extreme precision, to take account of the diversity of the population as a whole. In turn, this logic is quickly abandoned and, between 1871 and 1931, censuses are no longer interested in the ethnicracial composition of the population. Belize is then officially a British colony, and the assertion of the British presence and control of the territory seems to prevail over the administration of the various components of the population. Yet at the same time, in their many reports on Belize, the British administrators reproduce an invariable scheme, ignoring changes in the statistics and drawing a stereotypical representation of the trilogy ethnicity- identity-territory. In this interim period between colony and independent country, ethnic diversity is both a component of the colony, an 'invariable' in the eyes of the British administrators, and a statistical data without interest, because policies favour a territorial vision of administration.

After the beginning of a century marked by dramatic events (poverty, riots, hurricane) and the first anti-colonial demonstrations, the 1946 and subsequent censuses once again take into account ethnic and racial categories. They are much more technical and complete but, in a first stage, there seems to be a gap between the tool and the policy. In fact, the censuses are developed within the framework of the West Indies, with an explicit desire for uniformity in a region with increasing centrifugal dynamics, and they are sometimes quite ill-adapted to the particular situation of Belize. In 1981, with independence, censuses tend to integrate local usage and give value to categories of miscegenation ("Creoles" and "Mestizos"), which embody the new "national identity". However the new administration is not able to control its own tools and faces the emergence of an « unexpected nation » with a majority of Hispanic population. In parallel, some categories of ethnicity depart from an excluding hetero-denomination to a differentiated self-designation "standardized" at the international level (from "Caribs" to "Garifuna", from "American Indian", "Amerindian" or "Maya" to a recognition of the different Mayan groups, Yucatec, Mopan, Kekchi). 


\section{Bibliography}

Anderson, Benedict

2003 Imagined communities: reflections on the origin and spread of nationalism. London: New York, Verso.

Appelbaum, Nancy P., Anne S. Macpherson, Karin Alejandra Rosemblatt 2003 Race and Nation in Modern Latin America. Chapell Hill and London: the University of North Caroline Press

Ariel de Vidas, Anath \& Odile Hoffmann

2011 Beyond reified categories: multidimensional identifications among 'black' and 'Indian' groups in Columbia and Mexico, Ethnic and Racial Studies, http://dx.doi.org/10.1080/01419870.2011.594176

Ashdown, Peter

1985 The growth of black consciousness in Belize 1914-1919. The background to the exservicemen's riot of 1919. Belcast Journal of Belizean Affairs, 2 (2):1-5.

Badie, Bertrand

1995 La fin des territoires: essai sur le désordre international et sur l'utilité sociale du respect. Paris: Fayard.

Barnett, Carla Natalie 1991, .The political economy of land in Belize, "Machete must fly". Univ.West Indies Mona, $317 \mathrm{p}$.

Berkey, Curtis

1994 Maya land rights in Belize and the history of indian reservations. Report to the Toledo Maya Cultural Council, Indian Law Resource Center, Washington DC. 
Bolland, Nigel

1986 Belize. A New Nation in Central America. Boulder and London: Westview Press.

Bolland, Nigel

1997 Struggles for freedom: essays on slavery, colonialism and culture in the Caribbean and Central America. Belize City: Angelus Press.

Bolland, Nigel

2003 Colonialism and resistance in Belize: essays in historical sociology. Benque Viejo: Cubola Books.

Bristowe, Lindsay, and Philip Wright

1889 The Handbook of British Honduras, 1888-1889. Edinburgh and London: Blackwood.

Cal, Angel

1983 Anglo-Maya contact in Northern Belize: a study of British policy towards the Maya during the Cast War of Yucatan, 1847-1872. MA Thesis, University of Calgary, Alberta.

Camille, Michael A.

1996 Population and Ethnicity of Belize, 186. In Michael Phillips (ed.), Belize: Proceedings from the Second Interdisciplinary Conference. University Press of America, 45-63.

\section{CARSED}

2009 Le retour de la race. Contre les statistiques ethniques. Paris, Editions de L'Aube.

Cayetano, Sebastian, and Fabian Cayetano

1997[1990] Garifuna history, language and culture of Belize, Central America and the Caribbean. Bicentennial Edition (April $12^{\text {th }} 1797-$ April $12^{\text {th }}$ 1997). Belize: BRC.

Christopher, Anthony J. 
2005 Race and the Census in the Commonwealth. Population, Space and Place 11, 103-118

Cunin, Elisabeth

2001 La compétence métisse. Chicago sous les tropiques ou les vertus heuristiques du métissage. Sociétés Contemporaines, $\mathrm{n}^{\circ} 42$

Cunin Elisabeth

2012 Belmopan, nouvelle capitale du Belize indépendant. De la colonie caribéenne à la nation centre-américaine. No. 20.

Daugaard-Hansen, Flemming

2002 Negotiating national identity in Belize. Creole processes of identification and differentiation in Belize City. MA Thesis, University of Copenhagen.

Florescano, Enrique

1996 Etnia, estado y nación. Mexico: Taurus

González, Nancy

1969 Black Carib household structure. Washington: University of Washington Press.

Gould Jeffrey

1998 To Die in This Way: Nicaraguan Indian Communities and the Myth of Mestizaje, 18801965. Durham, NC, Duke University Press.

Grant, Cedric H.

1976 The Making of Modern Belize: Politics, Society and British Colonialism in Central America. Cambridge, Cambridge University Press

Hartog, François

2003 Régimes d'historicité. Présentisme et expériences du temps. Paris: Seuil. 
Izard, Gabriel

2004 Herencia y etnicidad entre los Garífuna de Belice. Revista Mexicana del Caribe 17:95-127.

Judd, Karen

1990 "Who will define US? Creolization in Belize". SPEAReport, 4: Second annual studies on Belize conference, 29-40.

Kertzer, David I., and Dominique Arel

2002 Censuses, identity formation, and the struggle for political power. In Census and Identity. The Politics of Race, Ethnicity, and Language in National Censuses. David I. Kertzer and Dominique Arel, eds. Pp. 1-42. Cambridge: Cambridge University Press.

Land In Crown Colonies And Protectorates

1912 (march). Colonial Office, HMSO

Lomnitz, Claudio

2001 Deep Mexico, Silent Mexico: An Anthropology of Nationalism. Minneapolis, University of Minnesota Press.

López Caballero, Paula

2011 Altérités intimes, altérités éloignées : la greffe du multiculturalisme en Amérique latine. Critique internationale $\mathrm{N}^{\circ} 51$.

Macpherson, Anne

2003 "Imagining the Colonial Nation: Race, gender, and Middle-Class Politics in Belize. 18881898”. In Nancy P. Appelbaum, Anne S. Macpherson, Karin Alejandra Rosemblatt, Race and Nation in Modern Latin America. Chapell Hill and London: the University of North Caroline Press, 108-131.

Macpherson, Anne 
2007 From Colony to nation. Women activists and the gendering of politics in Belize, 19121982. Lincoln and London: University of Nebraska Press.

May Zalasar, Lilia Selene

2010 Migración de mayas y yucatecos en Honduras Británica 1848-1883. Tesis de maestría en historia, CIESAS Peninsular.

Medina, Laurie Kroshus

1997 Defining Difference, Forging Unity: the co-construction of race, ethnicity, and nation in Belize. Ethnic and Racial Studies, 20(4):757-780.

Moberg, Mark

1992 Continuity under Colonial Rule: The Alcalde System and the Garifuna in Belize, 18581969. Ethnohistory, 39(1): 1-19.

Moberg, Mark

1997 Myths of ethnicity and nation: immigration, work, and identity in the Belize banana industry. Knoxville, University of Tennessee Press.

Nobles Melissa

2000 Shades of Citizenship: Race and the Census in Modern Politics. Stanford, Stanford University Press.

Palacio, Joseph

2005 The Garifuna. A nation across borders. Essays in social Anthropology. Benque Viejo del Carmen: Cubola Productions.

Palacio, Myrtle

1995 Redefining Ethnicity. The Experiences of the Garifuna and Creole in Post-Independence Belize. MA Tesis, New Orleans, University of New Orleans. 
Poiret, Christian, Odile Hoffmann, Cédric Audebert

2011 Contextualiser pour mieux conceptualiser la racialisation. Revue Européenne des Migrations Internationales 27 (1):7-16.

Price, Richard and Sally Price.

1995. Executing Culture: Musee, Museo, Museum. American Anthropologist, 97(1):97-109.

Reed, Nelson

2002[1964] La Guerra de castas de Yucatan. México: Biblioteca Era.

Reina, Leticia

2008 La etnización política: ¿necesaria para la construcción de la nueva nación mexicana? Memoria Americana 16 (2): 197-221

Shoman, Assad

1987 Party politics in Belize. 1950-1986. Benque Viejo del Carmen: Cubola Productions.

Shoman, Assad

1995 Backtalking Belize: selected writings. Edited by Anne Masherson. Belize City: The Angelus Press Limited.

Shoman, Assad

2000[1994] Thirteen chapters of a history of Belize. Belize City: The Angelus Press Limited.

Shoman, Assad

2010 Reflections on Ethnicity and Nation in Belize. Cuaderno de trabajo Afrodesc No. 9. http://www.ird.fr/afrodesc/spip.php?article338

Smith, Michael Garfield

1965 The Plural Society in the British West Indies. Berkeley: University of California Press. 
Soberanis, Antonio \& L. D. Kemp

1949 The Third Side of the Anglo-Guatemala Dispute. Belize City: Commercial Press.

Stone, Michael.

1994 Caribbean Nation, Central American State: Ethnicity, Race, and National Formation in Belize, 1798-1990. Ph.D. dissertation, University of Texas at Austin.

Tzec, Angel, Esther Sánchez, Deric Chan, Anita Tzec, Luis Galindo

2004 Iniciativa de Orientación General para el Desarrollo Estratégico de los Pueblos Indígenas, Belice. Bullet Tree Falls, Cayo, Belice, informe de la Cooperación Técnica ATN-JF-7695-BID (Marzo).

Villalobos González, Martha Herminia

2006 El bosque sitiado. Asaltos armados, concesiones forestales y estrategias de resistencia durante la Guerra de Castas. México, CIESAS-Conaculta-INAH-Porrua, Colección Peninsular.

Wilk, Richard

1993 Beauty and the feast: Official and visceral nationalism in Belize. Ethnos, 58 (3-4):244-255.

Wilk Richard

2006 Home cooking in the global village. Belizean food from Buccaneers to Ecotourists. Belize City: The Angelus Press \& London: Berg Publishers.

Wilk, Richard \& Mac Chapin

1990 "Ethnic minorities in Belize: Mopan, Kekchi and Garifuna". Speareports, 1.

Wimmer, Andreas

2008 The Making and Unmaking of Ethnic Boundaries: A Multilevel Process Theory, American Journal of Sociology, Volume 113 Number 4 (January 2008): 970-1022 
Caribbean Studies, Vol. 41, No. 2, July-December 2013, p. 31-60 
Table 1: Censuses from 1816 to 1931

\begin{tabular}{|c|c|c|c|}
\hline Date & Title & Categories & Author \\
\hline 1816 & $\begin{array}{l}\text { A census of the population } \\
\text { of the British Order of } \\
\text { Lieutenant Colonel George } \\
\text { Arthur } \\
\text { His Majesty's Settlement of } \\
\text { Belize on the Bay of } \\
\text { Honduras, taken by } \\
\text { Superintendent } \\
\text { Commandant, December } \\
\text { 1816 }\end{array}$ & $\begin{array}{l}\text { White } \\
\text { Coloured } \\
\text { Black } \\
\text { Slave }\end{array}$ & $\begin{array}{l}\text { Superintendant, } \\
\text { Belize }\end{array}$ \\
\hline 1820 & $\begin{array}{l}\text { Census } 1820 \text { of the slave } \\
\text { population for the British } \\
\text { Settlement (file title, original } \\
\text { missing) }\end{array}$ & $\begin{array}{l}\text { White } \\
\text { Coloured } \\
\text { Black } \\
\text { Slave }\end{array}$ & $\begin{array}{l}\text { House of Commons, } \\
\text { UK }\end{array}$ \\
\hline 1821 & $\begin{array}{l}\text { Census of the Slave } \\
\text { Population of the British } \\
\text { Settlement of Belize in the } \\
\text { Bay of Honduras, } 31^{\text {st }} \\
\text { December } 1821\end{array}$ & & $\begin{array}{l}\text { House of Commons, } \\
\text { UK }\end{array}$ \\
\hline 1823 & $\begin{array}{l}\text { Census of } 1823 \text { of the slave } \\
\text { population for the British } \\
\text { Settlement (file title, original } \\
\text { missing) }\end{array}$ & $\begin{array}{l}\text { White } \\
\text { Coloured } \\
\text { Black } \\
\text { Slave }\end{array}$ & $\begin{array}{l}\text { House of Commons, } \\
\text { UK }\end{array}$ \\
\hline 1826 & $\begin{array}{l}\text { Census of the population of } \\
\text { the British Settlement of }\end{array}$ & $\begin{array}{l}\text { White } \\
\text { Coloured }\end{array}$ & \\
\hline
\end{tabular}




\begin{tabular}{|c|c|c|c|}
\hline & $\begin{array}{l}\text { Belize, Honduras, } 1826 \text { (file } \\
\text { title, original missing) }\end{array}$ & $\begin{array}{l}\text { Black } \\
\text { Slave }\end{array}$ & \\
\hline 1829 & $\begin{array}{l}\text { Census of the Population of } \\
\text { the British Settlement, } \\
\text { Belize, Honduras }\end{array}$ & $\begin{array}{l}\text { White } \\
\text { Coloured } \\
\text { Black } \\
\text { Slave }\end{array}$ & \\
\hline 1832 & $\begin{array}{l}\text { Census of the Population of } \\
\text { the British Settlement of } \\
\text { Honduras for the year } 1832\end{array}$ & $\begin{array}{l}\text { White } \\
\text { Coloured } \\
\text { Black } \\
\text { Slave }\end{array}$ & \\
\hline 1834 & Slave Register & & \\
\hline 1835 & $\begin{array}{l}\text { Census of the Population of } \\
\text { the British Settlement of } \\
\text { Honduras for the year } 1835\end{array}$ & $\begin{array}{l}\text { White } \\
\text { Coloured } \\
\text { Black } \\
\text { Apprenticed labourer }\end{array}$ & \\
\hline 1840 & $\begin{array}{l}\text { Census of the Population of } \\
\text { the British Settlement of } \\
\text { Honduras for the year } 1840\end{array}$ & $\begin{array}{l}\text { White } \\
\text { Coloured } \\
\text { Black } \\
\text { Apprenticed labourer }\end{array}$ & \\
\hline 1861 & $\begin{array}{l}\text { Population census for } 1861 \\
\text { (file title, original missing) }\end{array}$ & $\begin{array}{l}\text { Anglo-Saxon, Anglo- } \\
\text { Honduran, Anglo-African, } \\
\text { Anglo-American, Anglo- } \\
\text { Indian, Anglo Hispanic, } \\
\text { Anglo French, Anglo Carib, } \\
\text { African, African-English, } \\
\text { African-Spanish, African } \\
\text { Indian, African Carib, } \\
\text { Indian, Indian African, } \\
\text { Indian Spanish, Indian } \\
\text { Carib, Spanish, Spanish \& } \\
\text { English, Spanish \& African, }\end{array}$ & Census Comisioners \\
\hline
\end{tabular}




\begin{tabular}{|c|c|c|c|}
\hline & & $\begin{array}{l}\text { Spanish \& Indian, Spanish } \\
\& \text { Carib, Carib, Carib \& } \\
\text { English, Carib \& African, } \\
\text { Carib \& Indian, French, } \\
\text { French \& Indian, French \& } \\
\text { Spanish, French \& } \\
\text { Portuguese, } \\
\text { Danish, } \\
\text { Portuguese \& French, } \\
\text { Belgian, Dutch, Syrian, } \\
\text { Chinese, Coolies, Italian, } \\
\text { French \& Italian, Not Stated }\end{array}$ & \\
\hline 1871 & $\begin{array}{l}\text { Census of 1871, enclosed in } \\
\text { Robert Harley to Grant, } 20 \\
\text { May 1872, CO123/148 } \\
\text { (cited by Bolland 2003: } \\
\text { 154) }\end{array}$ & & \\
\hline 1881 & $\begin{array}{l}\text { Unavailable in the } \\
\text { Belmopan archives }\end{array}$ & & \\
\hline 1891 & $\begin{array}{l}\text { Census of British Honduras } \\
\text { taken on the 6th of April, } \\
\text { 1891. }\end{array}$ & & $\begin{array}{l}\text { HY. O. Usher, Chief } \\
\text { Commissioner for the } \\
\text { Census }\end{array}$ \\
\hline 1901 & $\begin{array}{l}\text { Report on the result of the } \\
\text { census of the colony of } \\
\text { British Honduras, Taken on } \\
\text { the } 31^{\text {st }} \text { March, } 1901 \text { Belize: } \\
\text { Printed at Angelus Office, } \\
1901\end{array}$ & Not used & \\
\hline 1911 & $\begin{array}{l}\text { Report of the result of the } \\
\text { census of the colony of } B H \text {, } \\
\text { Taken on the } 2^{\text {nd }} \text { April, }\end{array}$ & Not used & \\
\hline
\end{tabular}




\begin{tabular}{|c|c|c|c|}
\hline & $\begin{array}{l}\text { 1911, Belize, Printed at the } \\
\text { Angelus Office, } 1912\end{array}$ & & \\
\hline 1921 & $\begin{array}{l}\text { Report on the Census of } \\
\text { 1921, Part 2. Tables, Taken } \\
\text { on the } 24^{\text {th }} \text { April, } 1921 \\
\text { Prepared by Herbert Dunk, } \\
\text { Register General and } \\
\text { Superintendent of Census } \\
\text { Printed by the Government } \\
\text { Printing Office, Belize, } \\
\text { British Honduras }\end{array}$ & Not used & $\begin{array}{l}\text { Herbert Dunk, } \\
\text { Register General and } \\
\text { Superintendent of } \\
\text { Census }\end{array}$ \\
\hline 1931 & $\begin{array}{l}\text { Census of British Honduras } \\
1931 \\
\text { Printed by the Government } \\
\text { Press } 1933\end{array}$ & Not used & $\begin{array}{l}\text { Major Sir John Alder } \\
\text { Burdon, Governor of } \\
\text { the Colony of British } \\
\text { Honduras }\end{array}$ \\
\hline 1946 & $\begin{array}{l}\text { West Indian Census } 1946 . \\
\text { Part E. Census of British } \\
\text { Honduras, } 9^{\text {th }} \text { April, } 1946 . \\
\text { Published by the } \\
\text { Government Printer, Belize, } \\
\text { British Honduras, } 1948 . \\
\text { Printed by the Government } \\
\text { Printer, Duke Street, } \\
\text { Kingston, Jamaica }\end{array}$ & $\begin{array}{l}\text { Black, Mixed or Coloured, } \\
\text { American Indian, Carib, } \\
\text { White, Syrian, East Indian } \\
\text { (Hindu), Chinese, Not stated }\end{array}$ & $\begin{array}{l}\text { Central Bureau of } \\
\text { Statistics of the } \\
\text { Government of } \\
\text { Jamaica }\end{array}$ \\
\hline 1960 & $\begin{array}{l}\text { West Indies Population } \\
\text { Census. Jamaica Tabulation } \\
\text { Center. Census of British } \\
\text { Honduras. 7th April, } 1960 . \\
\text { Volume 1. Department of } \\
\text { Statistics, Kingston, Jamaica }\end{array}$ & $\begin{array}{l}\text { African, Black, Negro; } \\
\text { European (or White); } \\
\text { Syrian; East Indian; Chinese } \\
\text { (and Japanese); Other races } \\
\text { and all the Mestizo groups }\end{array}$ & $\begin{array}{l}\text { Central Bureau of } \\
\text { Statistics of the } \\
\text { Government of } \\
\text { Jamaica }\end{array}$ \\
\hline
\end{tabular}




\begin{tabular}{|c|c|c|c|}
\hline 1970 & $\begin{array}{l}\text { Population Census of the } \\
\text { Commonwealth Caribbean. } \\
\text { Volume 7, Race and } \\
\text { Religion. Census Research } \\
\text { Programme, University of } \\
\text { the West Indies, } 1976 . \\
\text { Printed by the Herald } \\
\text { Limited, 43, East Street, } \\
\text { Kingston, Jamaica. }\end{array}$ & $\begin{array}{l}\text { Black, Mixed, Amerindian, } \\
\text { White, Portuguese, Syrian/ } \\
\text { Lebanese, East Indian, } \\
\text { Chinese, Other races, Not } \\
\text { stated }\end{array}$ & $\begin{array}{l}\text { University of West } \\
\text { Indies, Census } \\
\text { Research Programme, } \\
\text { Jamaica } \\
\text { Technical help from } \\
\text { the Canadian } \\
\text { International } \\
\text { Development Agency }\end{array}$ \\
\hline $\begin{array}{l}1980- \\
1981\end{array}$ & $\begin{array}{l}\text { Population Census of the } \\
\text { Commonwealth Caribbean } \\
\text { Belize, volume 1. Printed in } \\
\text { Jamaica. }\end{array}$ & $\begin{array}{l}\text { Creole, Mestizo, Maya, } \\
\text { Kekchi, Garifuna, White, } \\
\text { East Indian, Chinese, Other } \\
\text { races, Not stated }\end{array}$ & $\begin{array}{l}\text { Regional Population } \\
\text { Census and Regional } \\
\text { Census Co-ordinating } \\
\text { Committee } \\
\text { (Caricom). } \\
\text { Realized in Belize, } \\
\text { with the help of the } \\
\text { Statistical Institute of } \\
\text { Jamaica. } \\
\text { Technical help from } \\
\text { UN. }\end{array}$ \\
\hline 1991 & $\begin{array}{l}\text { 1991 Population Census. } \\
\text { Major Findings. Central } \\
\text { Statistical Office, Ministry } \\
\text { of Finance, Belmopan, } \\
\text { Cayo, Belize, C.A. } \\
\text { Population and Housing } \\
\text { Census, Administrative } \\
\text { Report. Central Statistical } \\
\text { Office, Ministry of Finance, } \\
\text { Belmopan, Belize CA }\end{array}$ & $\begin{array}{l}\text { Creole, Mestizo, Maya } \\
\text { Mopan, Kekchi Maya, } \\
\text { other Maya, Garifuna, } \\
\text { White, } \\
\text { German/Dutch/Mennonites, } \\
\text { Syrian/Lebanese, Indian, } \\
\text { Chinese, Others, DK/NS }\end{array}$ & $\begin{array}{l}\text { Central Statistical } \\
\text { Office, Ministry of } \\
\text { Finance, Belmopan. } \\
\text { Help of the Regional } \\
\text { Census Office } \\
\text { (Trinidad and } \\
\text { Tobago) }\end{array}$ \\
\hline
\end{tabular}




\begin{tabular}{|l|l|lr|l|}
\hline 2001 & Belize. Abstract of Statistics & Black/African, & Creole, & Central Statistical \\
2001. Central Statistical & Mestizo, Maya & Mopan, & Office, Ministry of \\
Office, Ministry of Finance, & Kekchi $\quad$ Maya, & Yucatec & Finance, Belmopan \\
Belmopan, November 2001 & Maya, & Garifuna, & \\
& & Caucasian/White, \\
& Mennonites, East Indian, & \\
& Chinese, Others, DK/NS & \\
\hline
\end{tabular}

Table 2: Reports

\begin{tabular}{|l|l|}
\hline Tittle & Years (available in the Belizean Archives) \\
\hline Blue Book & $\begin{array}{l}\text { From 1884 to 1944 } \\
\text { Missing years; 1889, 1896, 1904, 1906, 1916 1918, 1919, 1929, 1921, } \\
1939\end{array}$ \\
\hline $\begin{array}{l}\text { Colonial } \\
\text { Reports }\end{array}$ & $\begin{array}{l}1898,1899,1911,1916,1924-25,1926,1927,1929,1930,1931,1932, \\
1933,1934,1935,1936,1937,1938,1946,1947,1948,1950,1951, \\
1952,1953,1954,1955,1956,1957,1958,1959-1961,1962-1963, \\
1964-1965\end{array}$ \\
\hline $\begin{array}{l}\text { The Handbook } \\
\text { of British } \\
\text { Honduras }\end{array}$ & \begin{tabular}{l}
$1888-1889$ and 1925 \\
\hline
\end{tabular}
\end{tabular}


Table 3: Categories from 1946 to 2000

\begin{tabular}{|l|l|l|l|l|l|}
\hline 1946 & 1960 & 1970 & 1981 & 1991 & 2001 \\
\hline Black & $\begin{array}{l}\text { African, } \\
\text { Black, Negro }\end{array}$ & Black & & & Black/African \\
\hline $\begin{array}{l}\text { Mixed or } \\
\text { Coloured }\end{array}$ & & Mixed & Creole & Creole & Creole \\
\hline $\begin{array}{l}\text { American } \\
\text { Indian }\end{array}$ & & $\begin{array}{l}\text { Amerindia } \\
\mathrm{n}\end{array}$ & Maya & Maya Mopan & Maya Mopan \\
\hline East Indian \\
(Hindu)
\end{tabular}


Caribbean Studies, Vol. 41, No. 2, July-December 2013, p. 31-60

\begin{tabular}{|l|l|l|l|l|l|}
\hline Chinese & $\begin{array}{l}\text { Chinese (and } \\
\text { Japanese) }\end{array}$ & Chinese & Chinese & Chinese & Chinese \\
\hline & $\begin{array}{l}\text { Other races } \\
\text { and all the } \\
\text { Mestizo } \\
\text { groups }\end{array}$ & races & Other races & Others & Others \\
\hline Not stated & & Not stated & Not stated & DK/NS & DK/NS \\
\hline
\end{tabular}


Table 4: Census numbers from 1970 to 2000 in percentage

\begin{tabular}{|c|c|c|c|c|}
\hline & 1970 & 1981 & 1991 & 2001 \\
\hline $\begin{array}{ll}\text { Negro/ } & \text { Black, } \\
\text { Black/African } & \end{array}$ & 30.8 & & & 0.3 \\
\hline Creole & & 39.7 & 29.8 & 24.9 \\
\hline Mixed or Coloured & 32.8 & & & \\
\hline Mestizo & & 33.1 & 43.7 & 48.7 \\
\hline $\begin{array}{l}\text { Amerindian/ American } \\
\text { Indian/ Maya }\end{array}$ & 18.7 & & & \\
\hline & & 6.8 & & \\
\hline Maya Mopan & & & 3.7 & 3.9 \\
\hline Kekchi Maya & & 2.7 & 4.3 & 5.3 \\
\hline $\begin{array}{l}\text { Other Maya/ Yucatec } \\
\text { Maya }\end{array}$ & & & 3.1 & 1.4 \\
\hline Carib/ Garifuna & & 7.6 & 6.6 & 6.1 \\
\hline $\begin{array}{ll}\text { White/ European/ } \\
\text { Caucasian }\end{array}$ & 3.7 & 4.2 & 0.8 & 0.8 \\
\hline Portuguese & 0 & & & \\
\hline $\begin{array}{l}\text { German/Dutch/Mennon } \\
\text { ites }\end{array}$ & & & 3.1 & 3.6 \\
\hline $\begin{array}{l}\text { Syrian/ } \\
\text { Lebanese }\end{array}$ & 0 & & 0.1 & \\
\hline East Indian & 2.2 & 2.1 & 3.5 & 1.4 \\
\hline Chinese & 0 & 0.1 & 0.4 & 0.7 \\
\hline $\begin{array}{l}\text { Other races and all the } \\
\text { Mestizo groups/ } \\
\text { Others/ Not stated }\end{array}$ & 11.5 & 3.6 & 1 & 1.5 \\
\hline
\end{tabular}

